\title{
Increased Storage and Nutrition Content of Processed Foods through Vacuum Packaging
}

\author{
Niken Purwidiani \\ Culinary Departement \\ Universitas Negeri Surabaya \\ Surabaya, Indonesia \\ nikenpurwidiani@unesa.ac.id
}

\author{
Pirim Setiarso \\ Chemistry Departement \\ Universitas Negeri Surabaya \\ Surabaya, Indonesia \\ pirimsetiarso@unesa.ac.id
}

\author{
Nita Kusumawati \\ Chemistry Departement \\ Universitas Negeri Surabaya \\ Surabaya, Indonesia \\ nitakusumawati@unesa.ac.id
}

\begin{abstract}
Food is a basic need for human survival. Various vegetable and animal sources are used to fulfill this. Through the production of potato donuts and beef meatballs, Auliya SMEs has played an active role as one of the providers to fulfill this need. Along with increasing public awareness of food health, organoleptic quality and shelf life are two factors that also determine consumer interest in processed food products. To obtain a longer shelf life, it was evaluated and compared organoleptic quality and nutritional content of "Auliya" donuts and meatballs in vacuum and non-vacuum packaging. The results showed an increase in shelf life of $65.71 \%$ for potato donuts and $138.70 \%$ in beef meatballs which were vacuum packed. Vacuum packaging is also able to better maintain nutritional levels until a certain period of deviation. Meanwhile, under the same conditions, organoleptic test results showed no difference in the level of preference for food products in vacuum and non-vacuum packaging.
\end{abstract}

Keywords-donut, meatball, vacuum, shelf-life, nutritional content

\section{INTRODUCTION}

Food is a basic need for human survival. Various food sources are used to fulfill this, both vegetable and animal. One of the potential vegetable food sources to be developed is potatoes. Potatoes (Solanum tuberosum L.) is one source of vegetables in the form of tubers that contain lots of carbohydrates. In 100 grams of potatoes contained 19.1 grams of carbohydrates. In addition to carbohydrates, potatoes also contain protein, fat, vitamin $\mathrm{A}$, vitamin $\mathrm{B} 1$, vitamin $\mathrm{B} 2$, vitamin $\mathrm{C}$, phosphorus, iron, calcium, and calories from 83.0 to 85.0 cal. Apart from being the main food source, potatoes can also be developed into raw materials for more valuable vegetable food products, such as donuts [1]. Potato donuts are products that can reach all groups, from the bottom to the top.

In addition, animal food sources also support human nutritional needs as living things. One of the animal food source products is processed meat. Meat is a food that has high nutritional value because it is rich in protein, fat, minerals and other substances that are needed by the body [2-3]. Apart from being the main food source, meat can also be developed into a raw material to create a more valuable animal food product, one of which is a food product in the form of meatballs. Meatballs are food products that are generally in the form of spheres obtained from a mixture of livestock. In addition to vegetable, animal food sources also support the fulfillment of human nutritional needs as living things. Meat becomes one of the sources of animal food which has high nutritional value because it is rich in protein, fat, minerals and other substances needed by the body [2] [3]. Like donuts, meat can also be developed into raw materials for making more valuable animal food products, such as meatballs. Meatballs are food products that are generally spherical obtained from a mixture of livestock meat (meat content not less than 50\%) and flour or cereal with or without the addition of other food ingredients, and food additives are permitted [4]. Auliya SMEs is one of the food producer in Lamongan that has contributed to the supply of both types of food products. However, as with production problems in micro scale businesses, the quality of products produced is still relatively low.

The shelf life of food products is one of the most important information for consumers. The inclusion of shelf life information is very important because it is related to food product safety and to provide quality assurance when the product reaches consumers. Shelf life is related to a number of factors such as oxygen mass, water vapor, light, microorganisms, and compression of food products [5-6]. Shelf life is greatly influenced by the water content in food products, where this factor determines the growth rate of bacteria, fungi, and other microorganisms. The shelf life directly affects the nutritional content of food products, including carbohydrates, proteins, fats, and vitamins.

The quality of food products can decline even since the harvest [7]. This decrease can be caused by internal and external factors. Internal factors come from within the food products themselves, which occur naturally and spontaneously. While external factors are factors that originate from environmental conditions [8]. One external factor that affects shelf life, organoleptic properties and nutrient content is the packaging technique. Appropriate packaging techniques can delay or even deteralize quality so that the resulting product has a longer shelf life and has a relatively constant nutrient content during storage. Some packaging techniques include packaging with heat sealers, vacuum packaging, pressure packaging, and packaging with silica gel [9-11]. In this activity, a vacuum packaging technique was applied, which is done by removing all air in the package before it is sealed, to minimize contact, especially with oxygen and water vapor in the surrounding environment [12-15].

\section{MATERIAL AND METHODES}

\section{A. Material}

The ingredients for making potato donut dough include potatoes, eggs, granulated sugar, flour, butter, yeast, cooking 
oil obtained from the local market in Surabaya, Indonesia. Meanwhile, the ingredients for making beef meatballs, flour, tapioca flour, corn flour, chicken eggs, garlic, flavorings, pepper, ice cubes, and salt which are also found at the local market in Surabaya, Indonesia. Specifically for the application of vacuum packaging technology to "Auliya" potato donut and beef meatball products, used vacuum seal plastic obtained from Digitek Mart (Jakarta, Indonesia).

\section{B. Potato Donuts and Meatballs Making}

Making potato donuts begins with thorough stripping and washing. Potatoes were then cut and steamed for $1 \mathrm{~h}$. While waiting for the process of steaming the potatoes to finish, the dough was made by mix sugar, chicken eggs, and butter until evenly mixed. To it the potatoes that have been finely ground then were added. Stirring using a dough mixer was done until the dough was smooth. The dough was then formed in a small circle and waited for it to expand ( $\pm 90 \mathrm{~min})$. The dough was then fried until changed to brownish yellow.

The production of "Auliya" beef meatballs begins with the washing of fresh beef raw materials. Add salt and half of the ice to it and then chopped and stirring using a chopper. Soon after, flour, pepper, garlic, and the remaining ice ingredients were added. The chopping and stirring process was continued until evenly mixed. The dough was left for $10-15 \mathrm{~min}$ in the refrigerator and then was formed into a circle and boiled in boiling water until it was completely cooked $( \pm 15 \mathrm{~min})$

\section{Product Packaging}

"Auliya" potato donut and beef meatballs products were packaged using a Freshpack Pro-BT vacuum sealer.

\section{Shelf Life and Nutrition Content Analysis}

Shelf life analysis of "Auliya" potato donuts and beef meatballs was carried out using the "Total Plate Count" method with Plate Count Agar (PCA) medium. Meanwhile, the analysis of nutrient content which includes water, carbohydrate, protein, and fat content was carried out using a drying oven, the Luff Schoorl, Kjeldahl, and n-hexane extraction method.

\section{E. Organoleptic Test}

Organoleptic test of "Auliya" potato donut and beef meatball products was carried out by involving 50 panelists in the consumer category. Organoleptic parameters tested included the liking level for taste, smell, texture, appearance, and overall preference level.

\section{RESUlt AND DisCUSSION}

\section{A. “Auliya” Potato Donuts and Beef Meatballs Making}

Making potato donuts begins with potatoes stripping and washing thoroughly. Washing is one of the stages that determines quality, especially hygiene, where this process can prevent of various contaminants to potatoes. Potatoes were then cut and steamed for $1 \mathrm{~h}$ at $90-100^{\circ} \mathrm{C}$. Steaming is the process of food cooking that utilizes hot steam as its medium. During steaming, the material will lose some of its water content due to evaporation during the process. Water that evaporates is free water that can be a medium for microbial growth. This process must be carried out at the right temperature and time range so that the nutritional content in the product does not decrease or damage.

While waiting for the potatoes steaming process to be finished, a dough is made from a mixture of sugar, chicken eggs and butter. In the next step the potatoes were added to it. The donut mixture was then cut into small pieces, each of $25 \mathrm{~g}$ and then allowed to rise for $90 \mathrm{~min}$. Yeast activity will lead to the development of the dough. These microorganisms induce fermentation in the mixture, thus producing carbon dioxide which causes the mixture to expand. Besides $\mathrm{CO}_{2}$, ethyl alcohol will also be formed during fermentation. The alcohol that is formed will form a smell in the dough.

Reactions that occur when the dough is expanding:

$$
\begin{aligned}
& \mathrm{C}_{12} \mathrm{H}_{22} \mathrm{O}_{11}+\mathrm{H}_{2} \mathrm{O} \rightarrow 2 \mathrm{C}_{6} \mathrm{H}_{12} \mathrm{O}_{6} \text { ( invertase enzyme activity ) } \\
& \mathrm{C}_{6} \mathrm{H}_{12} \mathrm{O}_{6} \rightarrow 2 \mathrm{C}_{2} \mathrm{H}_{5} \mathrm{OH}+2 \mathrm{CO}_{2} \text { ( zymase enzyme activity ) }
\end{aligned}
$$

The potato donut dough cooking with the hot oil media gradually causes the surface of the donuts to turn brownish yellow. This brown color is the role of sugar in the dough. Sugar on the surface of the dough will undergo caramelization, which is a non-enzymatic browning process including the degradation of sugars in the absence of amino acids and the reaction of reducing sugars with proteins (Maillard's reaction). After oil draining using a spinner, "Auliya" potato donut products are ready to be packaged. Packaging was done using vacuum and non-vacuum packaging. Fig 1 shows the appearance of a vacuum and non-vacuum donut product. 


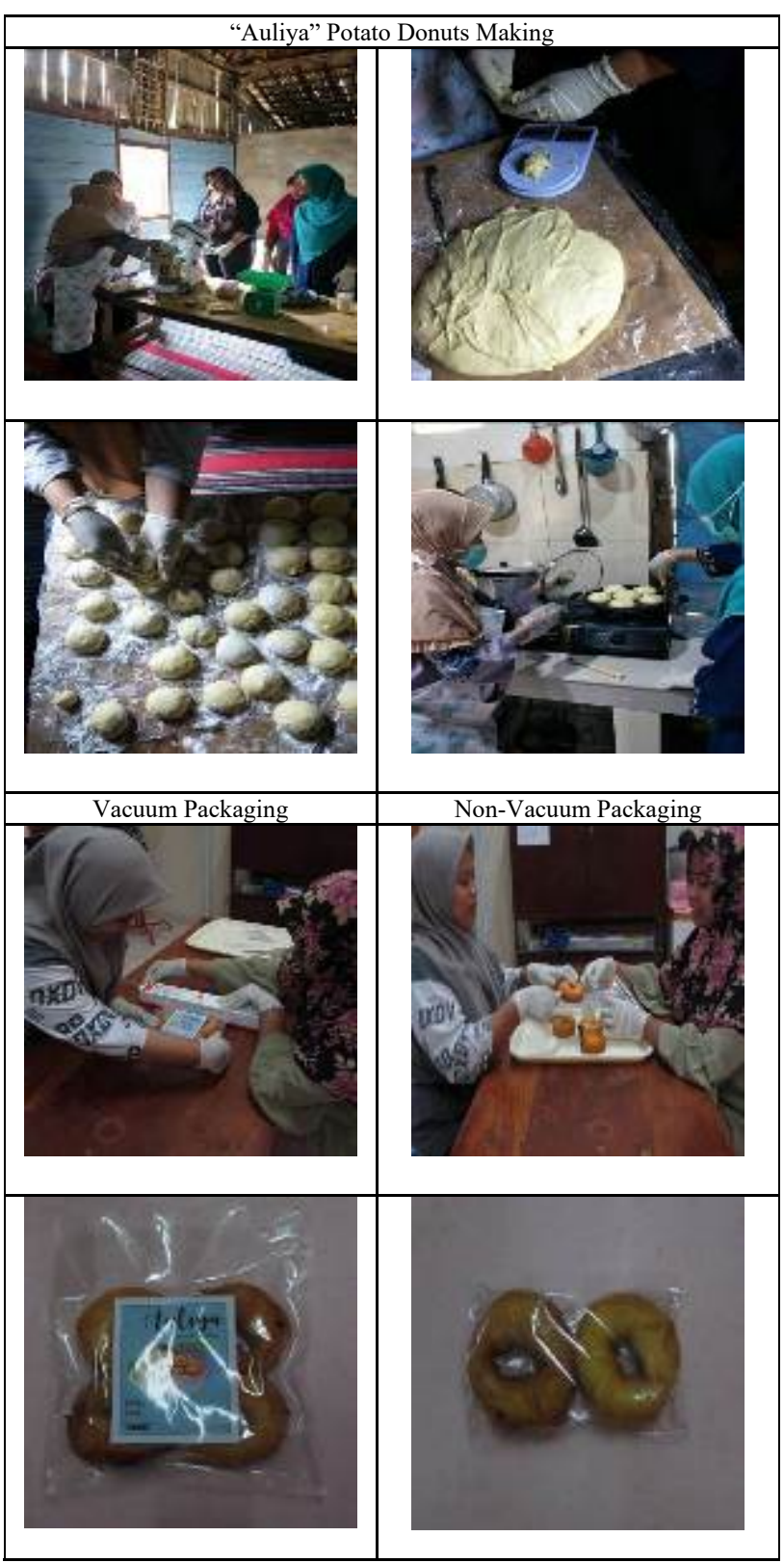

Fig. 1. Appearance of "Auliya" potato donut products in vacuum and nonvacuum packaging

Making beef meatballs begins with preparing the main ingredients in the form of fresh beef from the slaughterhouse without going through storage. Before processing, the meat was washed to remove the blood, fat, pigment, mucus, and water-soluble proteins. However, this washing must be done in the shortest possible time because it can cause changes in the color, odor, and elasticity of the beef used. Beef was then added with salt and ice, then chopped using chopper. In meatball dough, salt acts as a flavoring and preservative. To increase the suppleness and quality of the flavor, to the meatballs dough is added flour, pepper, garlic, and the remaining ice ingredients to it. The dough is then stirred until evenly mixed and the texture becomes smooth. The addition of ice to the meatball dough is as a substitute for water needed to dissolve the spices and keep the dough temperature low so that the potential for protein denaturation in the meat can be minimized. This is important to do, considering that during stirring, there will be friction between the dough and the machine which will increase the temperature during the process. In addition, stirring accompanied by the addition of ice can inhibit the activity of bacteria that can damage the nutrient content in the dough.

The dough is then allowed to stand for $10-15 \mathrm{~min}$ in the refrigerator. The dough is then printed and put in warm water for $10 \mathrm{~min}$. The meatballs are then boiled in boiling water until they are fully cooked $( \pm 15 \mathrm{~min})$. The cooked meatballs are characterized by a soft and chewy texture. Meatballs cooking stages are done in two stages so that the resulting meatballs do not shrink or even break due to drastic temperature changes. Meatball texture is the result of protein activity. Protein plays a role in binding and emulsifying fat during the process of crushing and cooking to produce meatballs with a soft and chewy texture. After that, beef meatball products are ready to be packaged using vacuum and non-vacuum packaging. Fig 2 shows the appearance of beef meatball products with vacuum and non-vacuum packaging.

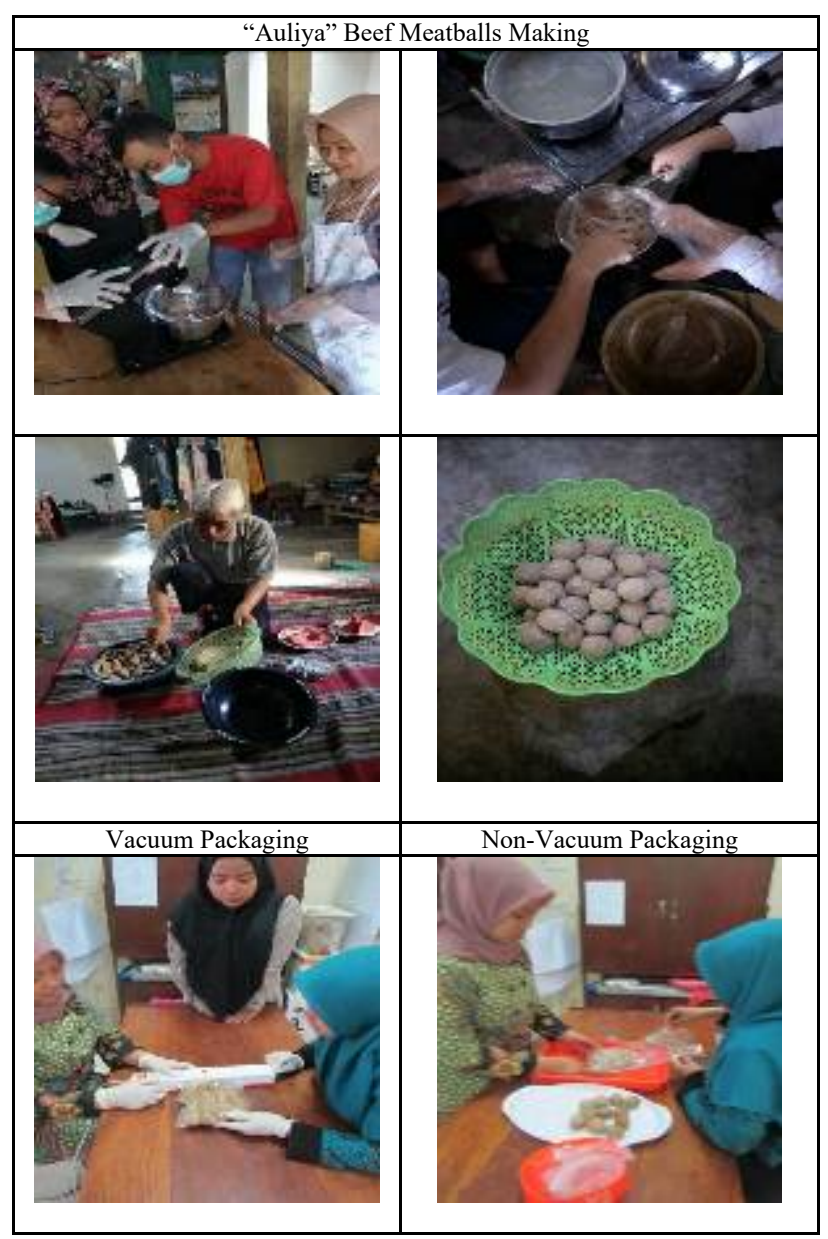




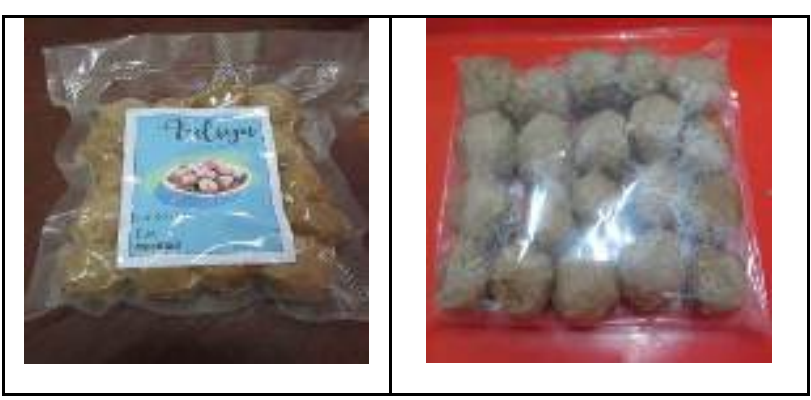

Fig. 2. Appearance of "Auliya" beef meatball products in vacuum and non-vacuum packaging

\section{B. Shelf-life Analysis}

The shelf life analysis is performed to determine the resistance of food products to malfunction in a certain time period. One factors that influence the shelf life of food products is packaging. In this case, the packaging becomes a barrier to the entry of oxygen. By minimizing the contact that occurs between food products with oxygen, the lower the rate of growth of the aerob microorganisms in it. The rate growth of the aerob microorganisms was carried out using the "Total Plate Count" method. Total Plate Count (TPC) test is intended to show the number of microbes contained in a product by containing bacterial colonies that are grown on Plate Count Agar (PCA) medium. Table 1 shows the results of the shelf life analysis of potato donuts and beef meatballs with vacuum and non-vacuum packaging. The use of vacuum packaging can increase the shelf life of potato donuts up to 5.8 days from only 3.5 days if they are packaged using non-vacuum. While beef meatballs with vacuum packaging can increase the shelf life from 3.1 days to 7.4 days.

TABLE I. ANALYSIS OF THE SHELF LIFE OF FOOD PRODUCTS

\begin{tabular}{|c|c|c|}
\hline \multirow[t]{2}{*}{ Food Products } & \multicolumn{2}{|c|}{ Shelf life (days) } \\
\hline & Vacuum Packaging & Non-Vacuum Packaging \\
\hline Potato Donuts & 5.8 & 3.5 \\
\hline Beef Meatballs & 7.4 & 3.1 \\
\hline
\end{tabular}

The use of vacuum packaging in food products has been able to increase the shelf life to $65.71 \%$ in potato donut products and $138.70 \%$ in beef meatball products. Vacuum packaging is done by using a vacuum sealer machine to remove the air in the packaging and then followed by gluing the packaging so that the packaging is completely free of oxygen. The presence of oxygen in the package will trigger the growth of microorganisms that can damage the quality of food products in it. Therefore, food products in vacuum packaging have a longer shelf life [16-17].

\section{Nutrition Content Analysis}

Nutrient content analysis at this stage was carried out to determine the nutritional security of "Auliya" food products after a specific shelf life. In Tables 4 and 5, the analysis of the nutritional content of potato donuts and beef meatballs in vacuum and non-vacuum packaging is shown respectively. Potato donut products in vacuum packaging contain carbohydrates, proteins, fats, and water respectively $55.62 \%, 7.68 \%, 16.82 \%$, and $19.88 \%$, whereas in nonvacuum packages have carbohydrates, protein, fat, and water content respectively reached $53.35 \%, 7.47 \%, 14.89 \%$, and $24.29 \%$. Furthermore, beef meatball products in vacuum packages contain carbohydrates, proteins, fats, and water respectively $40.53 \%, 9.61 \%, 22.90 \%$, and $26.96 \%$ while in non-vacuum packages have carbohydrates, proteins, fat, and water content respectively reached $39.73 \%, 8.88 \%, 21.82 \%$, and $29.57 \%$. Thus, the use of vacuum packaging can maintain nutrient content up to $4.25 \%$ for carbohydrates, $2.81 \%$ for protein, $12.96 \%$ for fat, and $22.18 \%$ for water content in potato donut products and respectively by $2.01 \%$ for carbohydrates, $8.22 \%$ for protein, $4.95 \%$ for fat and $8.83 \%$ for water content in beef meatball products.

TABLE II. NUTRITIONAL CONTENT OF “AULIYA” POTATO DONUT PRODUCTS

\begin{tabular}{|c|c|c|}
\hline \multirow[t]{2}{*}{ Parameters (\%) } & \multicolumn{2}{|c|}{ Food Products } \\
\hline & Vacuum Packaging & Non-Vacuum Packaging \\
\hline Carbohydrate & 55.62 & 53.35 \\
\hline Protein & 7.68 & 7.80 \\
\hline Fat & 16.82 & 14.89 \\
\hline Water Content & 19.88 & 23.96 \\
\hline
\end{tabular}

TABLE III. Nutritional CONTENT OF “AuliyA” BeEF MEATBAlls PRODUCTS

\begin{tabular}{|c|c|c|}
\hline \multirow[t]{2}{*}{ Parameters (\%) } & \multicolumn{2}{|c|}{ Food Products } \\
\hline & Vacuum Packaging & Non-Vacuum Packaging \\
\hline Carbohydrate & 40.53 & 39.73 \\
\hline Protein & 9.61 & 8.88 \\
\hline Fat & 22.90 & 21.82 \\
\hline Water Content & 26.96 & 29.57 \\
\hline
\end{tabular}

Specifically, the results of this analysis indicate a higher protein content in the "Auliya" processed food product in vacuum packaging. Related to this, the protein content will determine the texture and water binding capacity [18-20]. The higher the protein content, the better the water binding capacity and texture produced. Higher capacity of water binding indicates better quality of food products, where the capacity of water binding is inversely proportional to water content. The lower the water content, the longer the shelf life of food products. Food products in non-vacuum packaging have a higher water content because the air in the package turns into water vapor or better known as condensation.

\section{Organoleptic Test}

Organoleptic tests of potato donuts and beef meatballs were conducted on 50 panelists. Organoleptic parameters tested included color, smell, texture, taste, and overall level of preference. Organoleptic tests are also called sensory tests because they are based on sensory organ stimulation. Organoleptic test of non vacuum packaging was carried out on potato donuts and beef meatballs after 0 days storage. Organoleptic test of vacuum packaging is based on the results of the shelf life test, after 5 days of storage for potato donuts and after 7 days of storage for beef meatballs. Figure 3-6 shows the organoleptic test results of the panelists' preference level for the organoleptic properties of potato donuts and beef meatballs. The preference level are very like (VL), like (L), slight like (L), and dislike (D). 


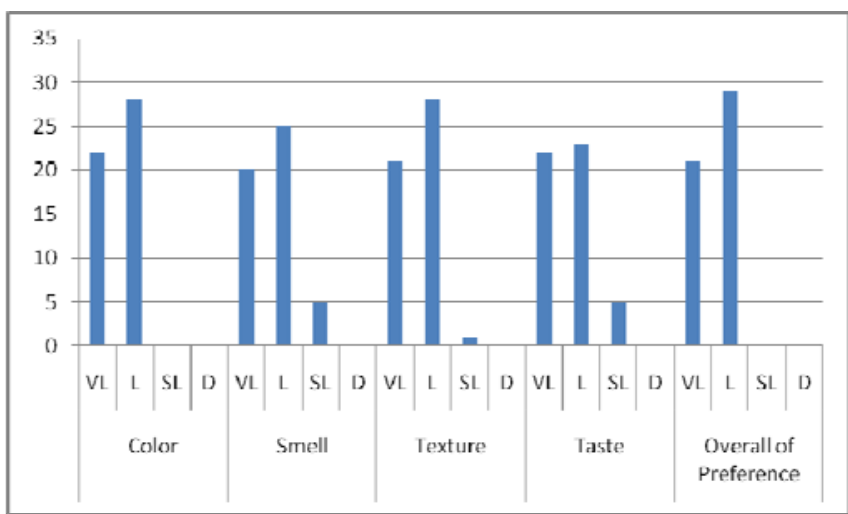

Fig 3. Organoleptic Test Result of Potato Donuts (0 day of storage)

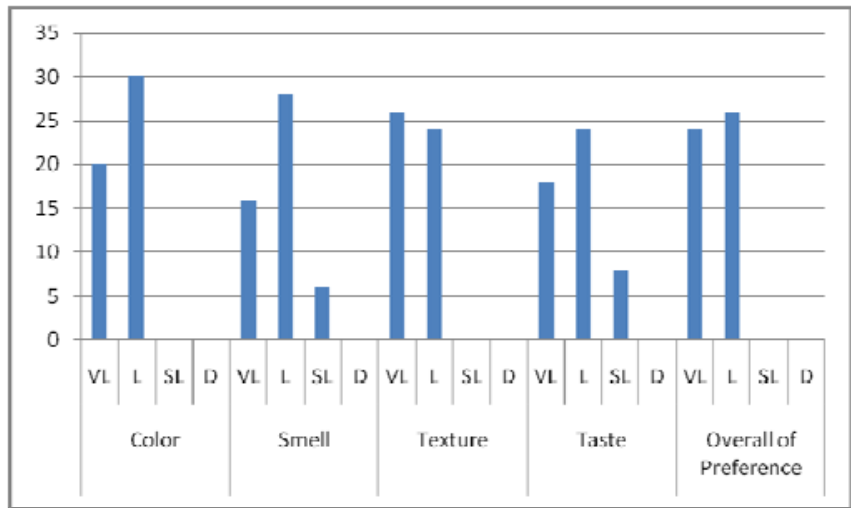

Fig 4. Organoleptic Test Result of Vacuum Packaged Potato Donuts (after 5 days of storage)

Organoleptic test results showed no significant differences in the level of preference for potato donuts in vacuum packaging even after 5 days of storage and beef meatballs in vacuum packaging even after 7 days of storage. This shows the success of vacuum packaging in controlling the occurrence of contact of food products with $\mathrm{O}_{2}$, water vapor and microorganisms so that it can inhibit deteorization which results in a low shelf life of the two processed food products. Thus, even though stored for a long period of time, vacuum packaging is able to help food products in packaging to maintain nutritional levels.

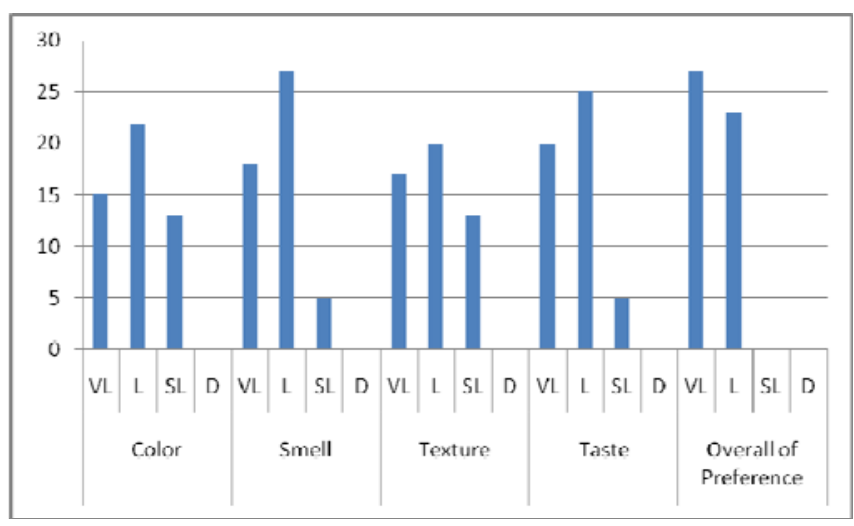

Fig 5. Organoleptic Test Result of Beef Meatball (0 day of storage)

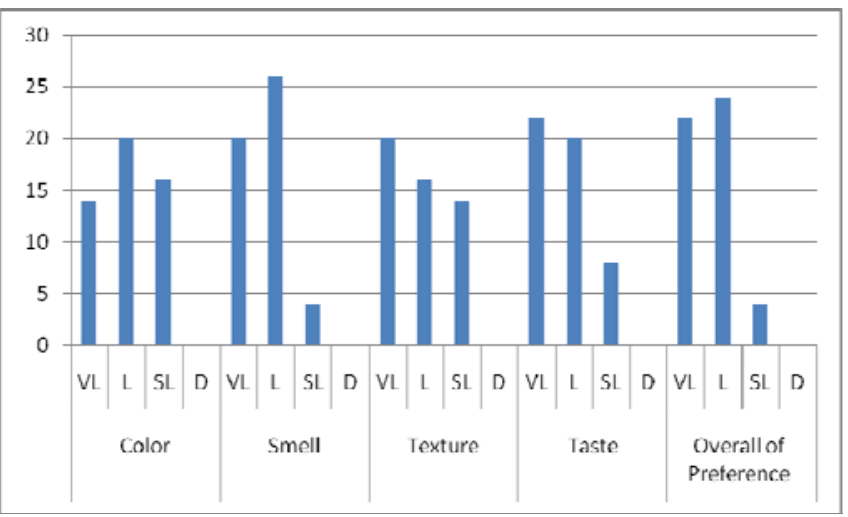

Fig 6. Organoleptic Test Results of Vacuum Packaged Beef Meatball (after 7 days of storage)

\section{CONCLUSION}

Vacuum packaging has increased shelf life in donut products by $65.71 \%$ and in beef meatball products by $138.70 \%$. Furthermore, in addition to increasing shelf life, vacuum packaging has also been able to maintain the nutritional content and organoleptic properties of potato donuts in vacuum packaging even after 5 days of storage and beef meatballs in vacuum packaging even after 7 days of storage.

\section{ACKNOWLEDGMENT}

The author would like to thank Universitas Negeri Surabaya for supporting infrastructure activities.

\section{REFERENCES}

[1] U. M. Arief, D. N. Setyaningsih, and S. Purbawanto, "Upaya Peningkatan Produksi dengan Menggunakan Alat Pengaduk Otomatis pada Usaha Donat Kentang di Semarang”, Abdimas, vol. 22(1), pp. 103-110. 2018.

[2] H. Yanti, Hidayati, and Elfawati, "Kualitas Daging Sapi Dengan Kemasan Plastik PE (Polyethylen) Dan Plastik PP (Polypropylen) di Pasar Arengka Kota Pekanbaru," Jurnal Petemakan, vol. 5(1), pp.2227. 2008.

[3] A. Purwanto, A. Ali, and N. Herawati, "Kajian Mutu Gizi Bakso Berbasis Daging Sapi dan Jamur Merang (Volvariella volvaceae)," Sagu, vol. 14(2), pp. 1-8. 2015.

[4] M. Ismail, R. Kautsar, P. Sembada, S. Aslimah, and I. Arief, "Kualitas Fisik dan Mikrobiologis Bakso Daging Sapi Pada Penyimpanan Suhu yang Berbeda," Jurnal Ilmu Produksi dan Teknologi Hasil Peternakan, vol. 4(3), pp. 372-374. 2016.

[5] A. Pudjirahaju, "Pengawasan Mutu Pangan," Pusat Pendidikan Sumber Daya Manusia Kesehatan Badan Pengembangan Dan Pemberdayaan Sumber Daya Manusia Kesehatan, 2017.

[6] H. Herawati, "Penentuan Umur Simpan Pada Produk Pangan," Jurnal Litbang Pertanian, vol. 27(4), pp. 124-130. 2018.

[7] D. Sundari, Almasyhuri, and A. Lamid, "Pengaruh Proses Pemasakan Terhadap Komposisi Zat Gizi Bahan Pangan Sumber Protein”, Media Litbangkes, vol. 25(4), pp. 235-242. 2015.

[8] M. Nur, "Pengaruh Cara Pengemasan, Jenis Bahan Pengemas, dan Lama Penyimpanan Terhadap Sifat Kimia, Mikrobiologi, dan Organoleptik Sate Bandeng (Chanos chanos)," Jurnal Teknologi dan Industri Hasil Pertanian, vol. 14(1), pp. 1-11. 2009.

[9] J. Djordjevic, M. Boskovic, M. Starcevic, J. Ivanovic, N. Karabasil, M. Dimitrijevic, and M. Z. Baltic, "Survival of Salmonella spp. in minced meat packaged under vacuum and modified atmosphere," Brazilian Journal of Microbiology, vol. 49(3), pp. 607-613. 2018. 
[10] C. Botta, I. Ferrocino, M. C. Cavallero, S. Riva, M. Giordano, and L. Cocolin, "Potentially active spoilage bacteria community during the storage of vacuum packaged beefsteaks treated with aqueous ozone and electrolyzed water," International Journal of Food Microbiology, vol. 266, pp. 337-345. 2018.

[11] R. D. A. Amaral, I. Achaerandio, B. C. Benedetti, and M. Pujola, "The influence of edible coatings, blanching and ultrasound treatments on quality attributes and shelf-life of vacuum packaged potato strips," LWT-Food Science and Technology, vol. 85, pp. 449455. 2017.

[12] D. Li, J. Zhang, S. Song, L. Feng, and Y. Luo, "Influence of heat processing on the volatile organic compounds and microbial diversity of salted and vacuum-packaged silver carp (Hypophthalmichthys molitrix) fillets during storage, Food Microbiology, vol. 72, pp. 7381. 2018

[13] L. Schuster, C. Franke, P. Silcock, J. Beauchamp, and P. J. Bremer, "Development of a novel sample reuse approach to measure the impact of lean meat, bone and adipose tissue on the development of volatiles in vacuum-packed chilled lamb stored at $2{ }^{\circ} \mathrm{C}$ for 15 days," Meat Science, vol. 145, pp. 31-39. 2018.

[14] P. Zhang, M. Badoni, M. Ganzle, and X. Yang, "Growth of Carnobacterium spp. isolated from chilled vacuum-packaged meat under relevant acidic conditions," International Journal of Food Microbiology, vol. 286, pp. 120-127. 2018.
[15] A. Lante, and F. Zocca, "Effect of $\beta$-cyclodextrin addition on quality of precooked vacuum packed potatoes," LWT - Food Science and Technology, vol. 43(3), pp. 409-414. 2010.

[16] F. Muliady, F. Hamzah, and Yusmarini, "Bakso berbasis jamur tiram putih dan ikan patin pada kondisi kemasan vakum, non vakum serta suhu dingin dan suhu beku selama penyimpanan," Jom Faperta, vol. 3(2), pp. 1-15. 2016

[17] M. Astawan, C. C. Nurwitri, Suliantari, and D. A. Rochim, "Kombinasi kemasan vakum dan penyimpanan dingin untuk memperpanjang umur simpan tempe bacem," Pangan, vol. 24(2), pp. 125-134. 2015.

[18] H. A. Sari and S. B. Widjanarko, "Karakteristik kimia bakso sapi (kajian proporsi tepung tapioka : tepung porang dan penambahan $\mathrm{NaCl}$ ), Jurnal Pangan dan Agroindustri, vol. 3(3), pp. 784-792. 2015.

[19] L. Chakim, B. Dwiloka, and Kusrahayu, "Tingkat kekenyalan, daya mengikat air, kadar air, dan kesukaan pada bakso daging sapi dengan substitusi jantung sapi," Animal Agriculture Journal, vol. 2(1), pp. 97104. 2013.

[20] S. Montolalu, N. Lontaan, S. Sakul, and A. D. Mirah, " Sifat fisikokimia dan mutu organoleptik bakso broiler dengan menggunakan tepung ubi jalar (Ipomoea batatas L.)," Jurnal Zootek, vol. 32(5), pp. 1-13. 2013. 